\title{
Viral Vector Preparation
}

National Cancer Institute

\section{Source}

National Cancer Institute. Viral Vector Preparation. NCI Thesaurus. Code C113055.

Cloning and isolation of viral vectors from producer cell lines or transiently infected cells. 